The 4th ICIBA 2015, International Conference on

\title{
Android-Based Bus Ticket Reservation Application
}

\author{
Fitriani, Leon Andretti Abdillah, Deni Erlansyah \\ Universitas Bina Darma \\ e-mail:viytriyani@ymail.com, leon.abdillah@yahoo.com,deni@mail.binadarma.ac.id
}

\begin{abstract}
Currently mobile phones are not only used as a medium to communicate to phone and sms only, but also as a medium to communicate directly via the Internet or packet data service (GPRS) to send and receive data. DAMRI is a state-owned enterprises engaged in the transportation field. For existing activities in the company such as booking tickets, search the scheduled departure time, and the price of a bus ticket so prospective buyer can only do it queued through the outlet/counters and via telephone only. The development method used in this study is Mobile Application Development. The authors aimed to create a mobile application android-based ticket reservation ( $m$-Reservation) application in order to facilitate the customer in activity booking tickets, viewing departure schedule, checking the list of reservations and seeing the info posted directly via android smartphone.
\end{abstract}

Keywords : Android application, m-Reservation, DAMRI

\section{INTRODUCTION}

Computer technology or information technology (IT) is able to collaborate with many other disciplines (Abdillah, Syafei, \& Hardiyansyah, 2007). One of the most progreessive applications on IT recently is mobile technology. Mobile phones are not only used as a medium to communicate to phone and sms only, but can be used as a medium to communicate directly with the internet to send and receive data. This led to high interest in a smartphones.

Mobile application development is the set of processes and procedures involved in writing software for small, wireless computing devices such as smartphones or tablets (Rouse, 2011). In this paper, authors would like to discuss how to develop mobile application for bus ticket reservation.

The Department of Motor Transport of the Republic of Indonesia (DAMRI) is a stateowned enterprises engaged in transport. However, existing separately in company activities DAMRI such as booking tickets, search departure schedule, and pay any prospective buyer can do it through the outlet/counter and via the phone just to get information about booking or see the price of the ticket. However, for booking tickets by phone subscribers often have difficulty contacting DAMRI, due to a busy telephone lines used due to the number of incoming calls to DAMRI this annoying and disappointing the buyer, so the buyer will have to wait a long time as well mngantri officer had overwhelmed in serving each subscriber in 
order tickets. Based on the above ways are pretty troublesome in service or book tickets over the counter. However, in line with the development of emerging technology, people's lifestyles began to experience a shift, when the first computerized activities, internet and telecommunication limited by place or location (fixed location). Now these things have to do in a mobile, including the use of a smartphone with android operating system.

Several publications have cover mobile application, such as: 1) Ticket reservation in Joglosemar Executive shuttle bus ((Panjaitan, Bahtiar, \& Endah, 2012), 2) Al Quran mobile learning (Sobri \& Abdillah, 2013), and 3) Cinema ticket reservation (Witono \& Susanto, 2014).

\section{RESEARCH METHODOLOGY}

This study was conducted from October 2014 through January 2015. The place and the location of this research is in Damri Corporation Palembang Jl. Colonel H. Barlian No. 848 Km. 9 Sukarame Palembang.

\subsection{Data Collections}

In preparing this study, the authors used several data collection methods,among others: 1) Methods of Observation: Direct observation in the field of aspects relating to the system requirements. Data collection was carried out directly on DAMRI. The data obtained from the observation list of reservations, list, etc. sitting position, and 2) Method of Library Studies: A method of data collection is done by finding relevant books, papers and other scientific sources, Internet sites or article text documents related or related to the issues discussed.

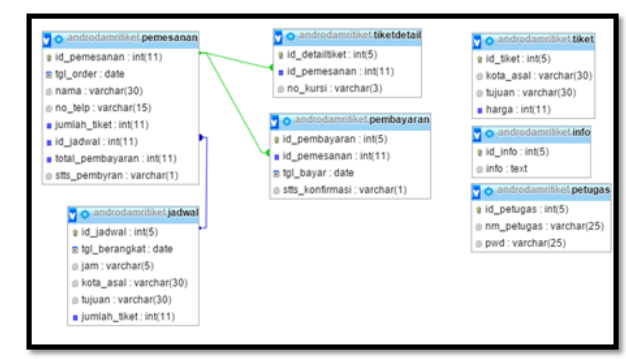

Figure 1: Database of mobile ticket reservation

\subsection{Mobile Application Development}

Mobile application development method used is a Mobile Application Development, consisting of six steps (Optimus Information, 2012): 1) Identify the Need also known as Requirements Gathering, 2) Create Mockups and/or Prototypes, 3) Finalize the Design and Create a Test Plan, 4) Development and Testing, 5) User Acceptance Testing (UAT), and 6) Deployment and Support. 


\subsection{Database Design}

In this research there are seven tables used in the mobile application: 1) Jadual, 2) Pemesanan, 3) Pembayaran, 4) TiketDetail, 5) Ticket, 6) Info, and 7) Petugas. Those collection of files are interrelated records, where those files could be manipulated (Abdillah, 2006).

\section{RESULTS AND DISCUSSION}

\section{$3.1 \quad$ Results}

The result of this research is a mobile applicatiton for e-ticket reservation (figure 2). This mobile application can help prospective passengers to get information regarding the departure schedule, ticket prices, etc. This application also enrich with database to help administrator in handling reservation data access to DAMRI.
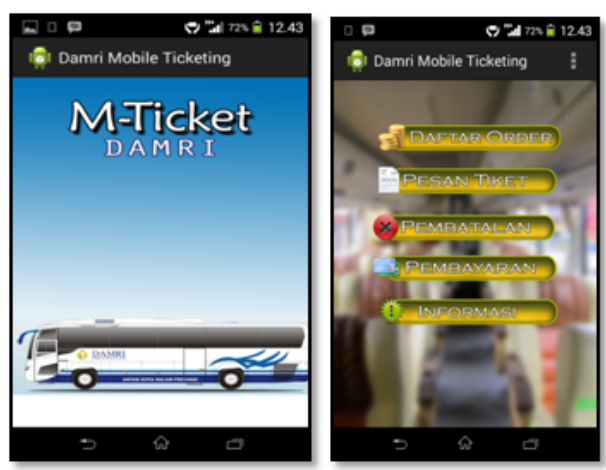

Figure 2: Main menu

Besides an application for mobile android, this research also produce a web application. This web application is used for admin to maintain the data of bus ticket reservations. Web application main menu (figure 2) describes the main menu page that appears after the officer to enter username and password correctly.

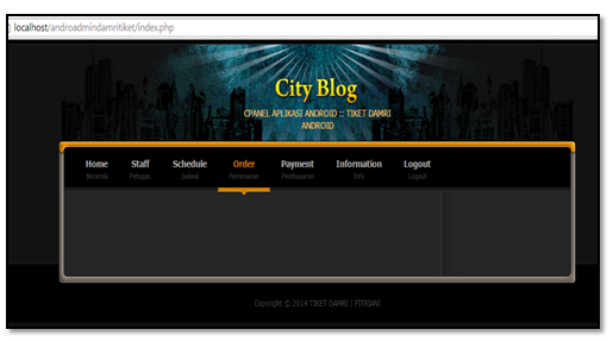

Figure 3: Main menu for web 


\subsection{Discussion}

Developed mobile application able to help passenger to browse, book the bus schedulle. This mobile application also able to help the passenger to choose where they would like to sit in the bus. As follows are some features of this mobile reservation application.

\subsubsection{Display the List of All Order}

Display a list of orders will show all orders which have been conducted by the passenger, so that they can see the ticket reservation status (canceled, pending or has been confirmed by admin).

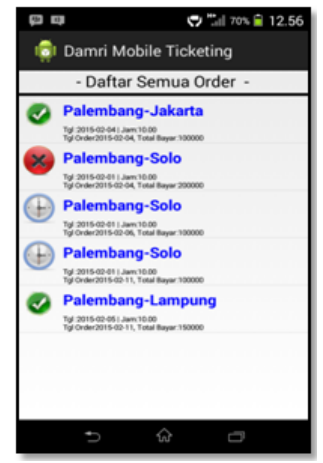

Figure 4: Display a list of orders

\subsubsection{Order Ticket}

This menu shows the origin and destination of passengers. This menu also used to choose bus departure schedule Figure 4. After passenger selects the destination then it will display the result of selected destination and schedulle.

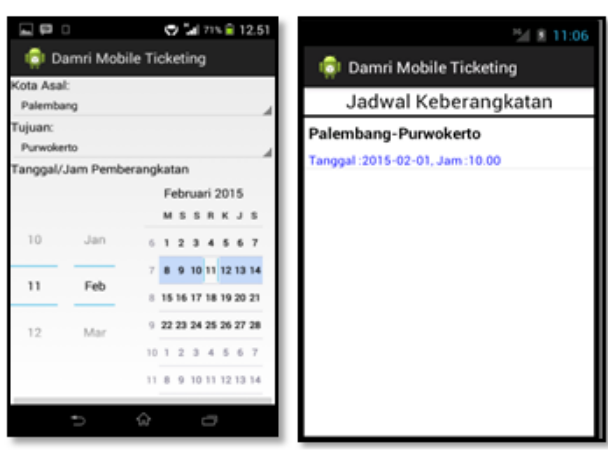

Figure 5: Booking scheduled departure 


\subsubsection{Choose the Sit}

After the passenger select the date for departure, then nest step is choosing where the passenger would like to sit int the bus. Figure 5 shows the posisition of every single sit in the bus (sit no 134 ).

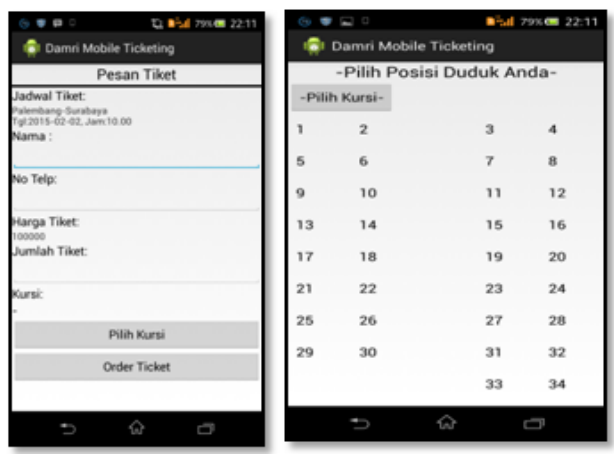

Figure 6: Ticket Order

\subsubsection{Payment Confirmation}

Payment confirmation displays the message to make the next payment after the passenger set an order. The message contains the amout of ticket price and where the account for payment should be transfered (figure 6 ).

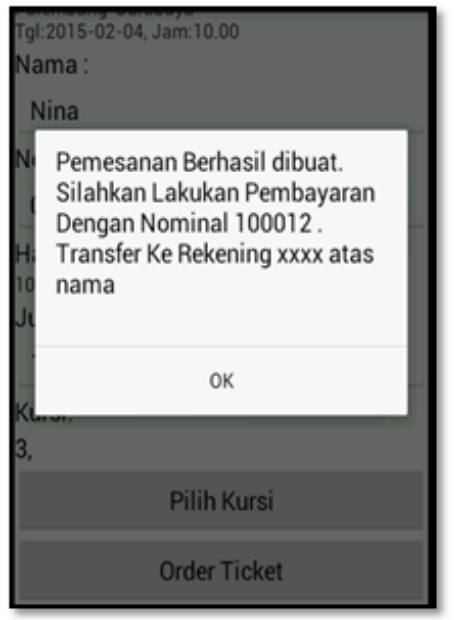

Figure 7: Payment Confirmation 


\section{CONCLUSION}

Based on the results of the study authors conducted at the University of Bina Darma and discussion conducted by the authors, it can be concluded that:

1. Application booking bus tickets android based DAMRI can shorten the time it takes to book a bus ticket, so the bus ticket booking application of DAMRI helps prospective buyer to book a bus ticket.

2. Application DAMRI bus ticket booking can display bus seating plan when the process of booking bus tickets, so the buyer can directly select the number of seats that the customer wants.

3. Applications android-based bus ticket booking is not only useful for the process of booking a bus ticket only, but this application can also display information such as the schedule departure, ticket prices and seating locations will be selected. So that a complete display of Opera- prospective buyer can more easily determine the schedule set out to be addressed.

\section{References}

Abdillah, L. A. (2006). Perancangan basisdata sistem informasi penggajian. Jurnal Ilmiah MATRIK, 8(2), 135-152.

Abdillah, L. A., Syafei, B. A., Hardiyansyah. (2007). Pengaruh kompensasi dan teknologi informasi terhadap kinerja dosen (KIDO) tetap pada Universitas Bina Darma. Jurnal Ilmiah MATRIK, 9(1), 1-20.

Optimus Information. (2012). Mobile Application Development Process, from http://www.optimusinfo.com/blog/mobile-application-development-process/

Panjaitan, P., Bahtiar, N., Endah, S. N. (2012). Sistem Pemesanan Tiket pada Joglosemar Executive Shuttle Bus Semarang. Jurnal Masyarakat Informatika, 2(4), 47-58.

Rouse, M. (2011). Mobile application development definition. Enterprise mobile application development: A CIO strategy guide, from http://searchsoa.techtarget.com/definition/Mobile-application-development

Sobri, M., Abdillah, L. A. (2013, 19 January). Aplikasi belajar membaca iqro' berbasis mobile. Paper presented at the Seminar Nasional Teknologi Informasi $\&$ Multimedia (Semnasteknomedia), STMIK AMIKOM Yogyakarta.

Witono, T., Susanto, R. (2014). Aplikasi Pemesanan Tiket Bioskop Berbasis Mobile. Jurnal Sistem Informasi, 7(2). 